\title{
The Qanun Jinayat Discriminates Against Women (Victims of Rape) in Aceh, Indonesia
}

\author{
Faradilla Fadlia, University of Syiah Kuala
}

Ismar Ramadani, Almuslim University

\begin{abstract}
This paper aims to analyze how the Qanun Jinayat, also known as the Islamic Criminal Law in Aceh, Indonesia, discriminates against women who are victims of rape. The Qanun Jinayat is a Criminal Law that regulates behaviour that is prohibited by sharia, such as Khamar (alcohol consumption), Maisir (Gambling) Khlawat (certain intimacy outside married), Ikhtilat (intermingling between women and men), Liwath (Homosexuality), Musahaqah (Lesbianism), Qadzaf (false accusation), Zina (fornication), sexual harassment, and rape. Punishments include caning, fines and imprisionment. ${ }^{1}$ In Article 52, Paragraph 1 of the Qanun Jinayat explains that victims of rape must provide evidence at the time of report. This clearly creates a double burden on female victims of rape because they have not only been the target of a horrific crime, but they must also present their own evidence and witnesses. Whereas in the Indonesian National Criminal Law (KUHP), evidence and witnesses are the responsibility of the investigator. This study examines how these discriminatory impacts are experienced by the victims (particulary women) after the Qanun Jinayat is implemented. Furthermore, this paper uses a qualitative method by utilizing indepth interviews. This research was conducted in Banda Aceh, Aceh, Indonesia. This paper concludes that the Qanun Jinayat has discriminated against women, especially the victims of rape, and this allows for the occurrence of injustice and violations of human rights.
\end{abstract}

Keywords: Qanun Jinayat, Gender Discrimination, Human Rights, Aceh

\section{INTRODUCTION}

Islamic Law, also known as the Qanun Jinayat, in conjunction with women's issues in Aceh, are objects of study that have been carried out by researchers with significant findings. Michael R Feener, from the Department of History at the National University of Singapore, published books including: Muslim Legal Thought in Modern Indonesia (Cambridge University Press, 2007) and Shari'a and Social Engineering: The Implementation of Islamic Law in Contemporary Aceh, Indonesia (Oxford University Press, 2013). Feener found that the application of Islamic Sharia Law in Aceh was originally carried out to rebuild and improve the territory

Zaki Ulya, "Dinamika Penerapan Hukum Jinayat Sebagai Wujud Rekonstruksi Syari'at Islam Di Aceh" (2016) 5:1 Jurnal Rechts Vinding: Media Pembinaan Hukum Nasional 135 at 137. 
after being destroyed by conflict and the Tsunami disaster in December 2004. Since then, the application of Sharia Law in Aceh has expanded in the entire jurisdiction of Aceh and has mixed with other social and legal traditions. The expansion of Sharia Law brings about traditional institutions to transform into legal institutions.

Feener furthermore focuses on individual institutions and actors involved in the implementation of Islamic Law in Aceh and the problems that were faced. ${ }^{2}$ So far, in his book, Feener tries to explain the institutions and actors created in the process of implementing Islamic Law and serves as a dictionary for Islamic Law in Aceh. Another study on the application of Islamic Law with a gender perspective was carried out by Dina Afrianti, a Research Associate for Gender, Religion and Law in the Muslim Community Program at the Center for Social Differences at Columbia University. Dina Afrianty has published a book titled Women and Sharia Law in Northern Indonesia: Local Women's NGOs and Islamic Law Reform in Aceh. Through this research, Afrianti examines how sexuality, the body, and women's faith have encountered new norms and expectations in Aceh through the application of Islamic Sharia Law.

This study raises three questions. First, there is the question of how women respond to the application of Islamic Law. The second question concerns how women activists understand their status in Acehnese culture and view gender relations in their society. Thirdly, the question arises of how these women activists reconcile their understanding of gender equality and women's rights regarding western values. Findings from this study include various responses about the application of Islamic Law; almost all of the responses criticize failure in the execution process. In addition, this study also found that there were weaknesses and errors in the preparation and implementation of the Qanun. ${ }^{3}$ In general, Afrianti's book presents comprehensive information about women and the dynamics of the implementation of Islamic Law in Aceh.

Aceh is a territory of Indonesia which has special autonomous status in accordance with Law Number 44 of 1999 concerning the administration of privileges for the region. This status allows special privileges when regulating four matters: Sharia Law, customs, education, and the role of the Ulama (or religious scholars) in the government structure. ${ }^{4}$ Aceh, better known as the 'Verandah of Mecca' (Serambi Mekkah), is an area that is thick with Islamic Sharia Law and is the only province in Indonesia that has implemented the Qanun. In addition, Aceh has

2 Michael R Freener, Shari'a and Social Engineering: The Implementation of Islamic Law in Contemporary Aceh, Indonesia, Oxford Islamic Legal Studies (Oxford, New York: Oxford University Press, 2014) at 1-3.

3 Dina Afrianty, Women and Sharia Law in Northern Indonesia: Local Women's NGOs and the Reform of Islamic Law in Aceh (Routledge, 2015) at 2-4.

4 Ulya, supra note 1 at 136. 

donesia

Sharia Police known as the Wilyatul Hisbah (WH). ${ }^{5}$ In Islamic Criminal Law, Jinayat, or Jarimah, are acts that are prohibited by religion and require the perpetrator to accept the consequences of the illegal actions. ${ }^{6}$

This study attempts to examine how Chapter 52, Clause 1 of the Qanun Jinayat has placed a double burden on, and therefore discriminates against, women. This is considered a double burden because evidence, which usually has been the responsibility of the investigator, has now been delegated to the rape victim. Aceh, as a privileged territory, has the special right to self-regulate its territory in accordance to Law No. 11 of 2006. This law designates that the government of Aceh has the authority to implement Sharia Law through the Qanun Jinayat. However, such authority should not contradict with the national constitutions and regulations. Aceh applies three legal systems that overlap each other: (1) the Qanun Jinayat, (2) Aceh customary law and (3) the Criminal Code (KUHP). ${ }^{7}$

Nursiti, a lecturer from Faculty of Law Science and the Department of Law Science at Syiah Kuala University, explains that if there are cases that can be resolved using the Criminal Code, the Qanun Jinayat, and customary law, the law enforcement agencies in Aceh agree that it is already included in the Lex Specialis. ${ }^{8}$ Referring to Chapter 5 of the Qanun Jinayat, ${ }^{9}$ when there are cases that can be resolved with the Qanun Jinayat, the Criminal Code, and customary law, the Qanun Jinayat is always chosen by law enforcement officers because the Qanun Jinayat is considered a Lex Specialis for Aceh. ${ }^{10}$ But, in handling cases, there are peculiarities, especially for cases of rape, where law enforcement officers decide to use the Criminal Code because it is considered more burdensome than the Qanun Jinayat. However, regarding implementation, the Qanun Jinayat is more widely used. This demonstrates that there is no legal mechanism to choose between the Qanun Jinayat, the Criminal Code, and customary law for certain cases.

5 Ma Theresa R Milallos, "Muslim veil as politics: political autonomy, women and Syariah Islam in Aceh" (2007) 1:3 Cont Islam 289.

6 Hasnil Basri Siregar, "Lessons Learned from the Implementation of Islamic Shari'ah Criminal Law in Aceh, Indonesia” (2008) 24:1 Journal of Law and Religion 143 at 158.

7 Redaksi, "Qanun Jinayat Aceh Langgar Hukum Nasional dan Internasional”, (22 October 2017), online: SEJUK <http://sejuk.org/2017/10/22/qanun-jinayat-aceh-langgar-hukum-nasionaldan-internasional/s.

8 lex specialis is the doctrine explains that if two laws govern the same factual situation, a law governing a specific subject matter (lex specialis) overrides a law governing only general matters (lex generalis).

9 Qanun Jinayat Article 5 this Qanun applies to (a) every Muslim who does Jarimah (crime) in Aceh; (b) Every non-Muslim person who does Jarimah in Aceh together with Muslims and chooses and submits voluntarily to the Jinayat Law; (c) Any religious person who is not a Muslim who commits Jarimah acts in Aceh that are not regulated in the Criminal Code (KUHP) or criminal provisions outside the Criminal Code, but regulated in this Qanun; and (d) A Business Entity running a business in Aceh.

10 Interview with Nursiti lecturer from the Faculty of Law Science: Department of Law Science, Syiah Kuala Univeristy, July 2, 2018. 
This has resulted in law enforcement agencies having greater power in deciding which law will apply to the perpetrators of certain cases; therefore, there are multiple interpretations and differences of handling cases. These multitudes could potentially discriminate already marginalized groups, in this case, women.

The Qanun Jinayat, which began in force on October 23, 2015, demonstrates the tendency to discriminate against women. Nissa Yura, the National Program Coordinator of Women Solidarity, said that the Qanun Jinayat is unable to protect women in Aceh from violence and, thus, strengthens the potential for criminalisation and discrimination against women. ${ }^{11}$ This is especially apparent in Article 52, Paragraph 1 which mentions, "anyone who is raped can file a complaint with the investigator about the person who raped her by including the initial evidence." Whereas, in the Criminal Code (Criminal Procedure), the preliminary evidence is charged to investigators in accordance with Article 1, Point 2 of Law Number 8 of 1981. This sections explains that "investigators are a series of investigative actions in respect of and in accordance with the manner laid down in this law to seek and collect evidence which with such evidence makes light of the criminal offence committed to finding a suspect." ${ }^{12}$ Article 52, Paragraph 1 of the Qanun Jinayat clearly creates a double burden for female victims of rape due to the requirement that they provide the preliminary evidence. The Qanun Jinayat, in Article 52, Paragraph 1, incriminates female victims of sexual violence to receive justice because she must be able to give a preliminary evidence of rape before the court. Necessarily, the courage of victims to report cases of rape should be commended; however, because of the existence of Article 52, Paragraph 1, in the Qanun Jinayat, victims are discouraged to report cases of sexual violence or rape. ${ }^{13}$

In addition, there are other problems which concern an oath which may be considered evidence. Article 56 states, "When both take the oath as mentioned in Article 53, then both are released from uqubat (punishment)." In the Qanun Jinayat, if there is no sufficient evidence the victim and the perpetrator may file an oath. There are two consequences of this oath. First, if the perpetrator swore that the perpetrator did not commit rape and the victim also makes an oath of not committing adultery, then both parties may be exempt from punishment. The second consequence is, if the perpetrator makes an oath but the victim does not file one, the victim may be exposed to the Jarimah (crime) Qadzaf (false accusation). This article may cause a rape victim to become a case of slander or Qadzaf (ac-

11 Heyder Affan, "Dianggap merugikan, Perda Syariat Islam di Aceh diusulkan ditinjau", (23 October 2017), online: <https://www.bbc.com/indonesia/indonesia-41714022>.

12 Kholidah Siah, "Tinjauan Yuridis Terhadap Pembuktian Jarimah Pemerkosaan Dalam Qanun Aceh Nomor 6 Tahun 2014 Tentang Hukum Jinayat”, (26 September 2016), online: ETD Unsyiah <http://etd.unsyiah.ac.id/index.php?p=show_detail\&id=25513>.

13 Reza Gunadha, "Diskriminatif, Qanun Jinayat Aceh Akan Diadukan ke MK - News Suara.Com", online: <https://www.suara.com/news/2017/10/16/174139/diskriminatif-qanunjinayat-aceh-akan-diadukan-ke-mk>. 

donesia

cusing a person of committing adultery without being able to file at least four witnesses). ${ }^{14}$ This article discriminates against victims, especially women, because it requires the victim to provide four witnesses to prove the rape was perpetrated by the accused. To find four witnesses who saw the incident of rape can be said to be almost impossible. Under these circumstances, if there is not sufficient evidence, the rape victim may turn into a perpetrator of adultery. This demonstrates that the application of the Qanun Jinayat places women in the position to be layered victims; the first being the victim of the perpetrators who committed the rape and the second as a victim of the authorities through the law.

The introduction above shows the overlap of the Criminal Code, Qanun Jinayat, and customary law. The burden of proof is charged to the victim as well as the burden of swearing an oath along with the offender in which the perpetrator can by relieved of the indictment. All three of these issues show that the Qanun Jinayat has discriminated against the victims of rape. This paper seeks to examine how the application of the Qanun Jinayat has discriminated against rape victims, especially in women.

\section{EVIDENCE AND TESTIMONY}

The Qur'an and Hadith are the main sources for Islamic Law that regulate all aspects of Muslims' public and private lives. These laws relate to religious worship, prohibitions, and all the obligations of Muslims in social life that include inheritance, divorce, punishment, conduct of war, and state administration. The science that studies Islamic Law is called Fiqah and Islamic Jurists are called Faqih and Fuqaha (plural). If there are cases that are not regulated in the Qur'an and Hadith, in Islamic Law there is room for Ijtihad which is a truly serious effort to seek knowledge so that it can decide something (a case) that is not discussed in the Qur'an and Hadith. ${ }^{15}$

Criminal acts in Islamic Law, or Jarimah, covers three things: Qisas, Ta'zir, and the Hadd and Hudud (plural). These terms are defined as obstacles, prevention, and prohibitions. Hudud are considered as the rights of God and refers to sanctions whose form and number of sentences have been determined in the Qur'an and Hadith. Qisas is related to retribution and considers the family rights of victims or legal guardians. In the case of a murder sentence, Qisas gives the victim's family the right to request the death penalty for murderers if approved by the court. Ta'zir is a sanction in the form of punishment which has not been ex-

14 Siah, supra note 12.

15 Qureshi, "The Four Schools of Law in Islam", (7 February 2014), online: Understanding Islam <https://free-islamic-course.org/stageone/stageone-module-4/four-schools-law-islam.html>. 
plained in the Qur'an and Hadith because it has been left for the wisdom and discrection of the authorities. ${ }^{16}$

Islam is divided into two schools: Sunni and Shi'a. ${ }^{17}$ This paper examines the opinions of Islamic Jurists who represent the four Sunni schools of law (or Madhabib) and Shi'a school of law, or Imami Shi'a (the Imamiyya school). The Sunni school consists of the Hanafiyyah, the Malikiyya, the Safiyya, and the Hanbali schools of religious law. Meanwhile, the Imamiyya School is usually associated with Faith Ja'far Al-Sadiq, descendants of Prophet Muhammad and the sixth Imam in the line of Imami Shi'a. ${ }^{18}$ The majority of Muslims (Sunni) gave the right to independent reasoning only to these four theologians and jurists who lived during the first three centuries of Islam. The four Fuqaha were Imam Abu Hanifa of Kuta, Iman Malik Bin Anas of Medina, Imam Muhammad Al-Shafi of Medina, and Imam Ahmad bin Hanbal of Baghdad. These four, great jurists and theologians tried to systematise Islamic Law into a comprehensive, rational system that covers all possible legal situations. These four, prominent schools of Islamic law are named according to their founders and they are known as the Hanafiyyah, the Malikiyya, the Safiyya, and the Hanbali schools of religious law. For Sunni Muslims, the four schools are considered as a valid interpretation of Islamic Law. These four schools recognise the Qur'an and Hadith as the main reference sources in Islamic Law. These four schools use independent reasoning which causes differences in some views on several cases. ${ }^{19}$

The Ulama ${ }^{20}$ (Muslim scholars) agree that the act of adultery can be proved by two things: confession and testimony. However, the Ulama differ on the confession conditions that are considered to be valid. The difference centers how many times confessions should be stated and what happens if the defendant withdraws the confession. The Malikiyya and the Safiyya agree that a one-time confession is considered legitimate. The Hanafis, the Hanbalis, and the Immaiyya agree that the recognition should be done as many as four times so that the confession can be considered valid. In addition to the revocation of the confession, the majority of Islamic jurists, except the Immamiya, agree that if the defendant withdraws the confession before the sentence is imposed, the accused should be released. $^{21}$

\footnotetext{
16 Abdel Salam Sidahmed, "Problems in Contemporary Applications of Islamic Criminal Sanctions: The Penalty for Adultery in Relation to Women" (2001) 28:2 British Journal of Middle Eastern Studies 187.

17 Michael Bohlander \& Mohammad M Hedayati-Kakhki, "Criminal Justice under Shari'ah in the 21st Century-An Inter-Cultural View” (2009) 23:4 Arab Law Quarterly 417.

8 Sidahmed, supra note 16 at 190.

19 Qureshi, supra note 15.

20 The Ulama is a group of muslim scholar who are recognised to have specialised knowledge of the sacred law and theology of islam.

21 Sidahmed, supra note 16 at 192.
} 

donesia

Concerning the testimony of Sharia Law experts, it is agreed that there should be four honest and credible eye-witnesses (that are men) to make valid testimonies. In addition, the Ulama agreed that the four witnesses should testify unanimously and explicitly that they had seen the fornication between the two adulterers. ${ }^{22}$ The Ulama also agree that the four witnesses should provide personal, verbal evidence and should corroborate their respective testimonies concerning the time, place, and any other important details. A husband's testimony is acceptable as long as he acts as a witness and not as an accuser. Moreover, a wife accused of adultery by her husband can take an oath to avoid the punishment of Hudud, if there two conditions are met. The first condition is one in which the husband who accuses the wife of committing adultery cannot present witnesses, and the second is if the husband does not admit that the child conceived by his wife is his child. For these two conditions, the wife can take an oath to deny the allegations and the judge will decide to divorce. Regarding the issue of how many witnesses in the case of adultery are considered legitimate, the majority of Ulama agree on four men. Only the Imammiyya hold that the testimony of three men and two women or two men and four women is acceptable. The Imammiyya also argue that a judge may impose a penalty without asking for further evidence if the judge sees the incident himself. ${ }^{23}$

The Ulama argue over whether a pregnancy can serve as proof of an adulterous act of a woman without a husband. The Malikiyya believe that women who are pregnant should be treated as though they are not guilty of adultery unless there is evidence that there has been a rape. The majority of Ulama agree that pregnancy is not necessarily considered proof as an act of adultery because of the possibility of duress or other conditions. The Ulama agree that there is no evidence to be asked of a woman claiming to be raped or a victim of unintentional sexual intercourse with a man which eventually leads to pregnancy. This refers to one of the events in the time of Umar bin Khattab ${ }^{24}$ where there was a woman who had been pregnant without a husband. Her testemony states, "I am a woman who is a heavy sleeper; a man had sexual intercourse with me while I was asleep, but I did not wake up until he had finished." Thus, the punishment of hudud against the woman was remitted. The Ulama agree that the hudud punishment should be avoided or canceled if there is any doubt or uncertainty of the judiciary (shubha). Prophet Muhammad, himself, firmly stated: "Wherever possible prevent the imposition of hudud against Muslims, and if there is for him (the accused) a way out, then set him free; for the Imam to err in pardoning is better than to err in punishment." Fortification is a case where there is the greatest space for the occurrence of doubt. An example of this is a testimony that is not complete either in

Ibid at 193.

23 Ibid.

24 Umar bin Al-Khattab was the second caliph who succeeded Abu Bakr Ash Shidiq, he was nicknamed as Al Faruq people who could separate truth and evil. 
the form of information and number of witnesses. Inadequate and contradictory evidence against each other is like a testimony different from evidence and delays in the implementation of hudud can also make the perpetrator doubt and drop the hudud. ${ }^{25}$

\section{EVIDENCE IN THE CASE OF FORTIFICATION IS THE SAME AS IN THE CASE OF RAPE}

It is very difficult to conduct investigations, verification, or restitution of rape cases in Sharia courts. If the justification and references set by classical jurisprudence are followed, the best thing a judge can do is to receive a statement from the victim that a raped occurred. Even if this resulted in the fall of the Hudud punishment against the victims, it cannot heal the physical and mental wounds of rape. The main problem in the implementation of Sharia Law is the tendency to treat rape cases as a form of adultery. Legal contacts blur the line against the two different offences. Where adultery is a sexual relationship based on awareness and consent from both parties, rape uses coercion from one of the parties, namely the perpetrator against the victim. In the act of adultery there are two perpetrators who violate Islamic Law, but in rape cases there are perpetrators and victims. The problems with the failure to separate the act of fornication and acts of rape provide two conditions: first, it opens the door to treating rape victims as perpetrators of adultery and, secondly, there is difficulty in finding evidence and it is almost impossible to prove rape cases when there is the required testimony of four people. $^{26}$

\section{OVERLAPPING POSITIVE LAW OF THE CRIMINAL CODE, THE QANUN JINAYAH, AND CUSTOMARY LAW}

The overlap of law enforcement of the Criminal Code, the Qanun Jinayah and customary law leads to the absence of fair trial principles. As an example, in a rape case against a child, law enforcement officials may choose whether the case should be resolved by the Criminal Code or using the Qanun Jinayat. When law enforcement officials feel that perpetrators should be subjected to heavier penalties, they will choose to use the Criminal Code; however, on other occasions for the same case, the legal apparatus can choose to use the Qanun Jinayat. According to Nursiti, legal apparatuses faced with cases that can be resolved by the Criminal Code and the Qanun Jinayat will immediately agree to implement the Qanun Jinayat. Nursiti states, "when we discuss with law enforcement officials they will say that there is already a Lex Specialist. Why the choice is then Qanun because they consider Qanun Jinayat the Lex Specialist for Aceh. If it is regulated in the

25 Sidahmed, supra note 16 at 193.

26 Ibid at 198-199. 

donesia

Qanun we use the Qanun."27 It appears that, for law enforcement officers, the Lex Specialist argumentation is considered influential and does not require any other explanation on the choice of law enforced. The Qanun Jinayat regulated its validity in Article 5, which regulates the legal subject of every person. This article states that, in criminal law, the case that can be-regulated by the Criminal Code or other laws, (the Qanun Jinayat), then the Qanun Jinayat will be enforced because Qanun Jinayat is consider the Lex Specialist for Aceh. This is except for nonMuslims, who may choose which law shall be elected. Thus, the Qanun Jinayat only applies to Muslims who have committed felony offenses in the jurisdiction of Aceh. Therefore, if there is a case that the victim or perpetrator is a Muslim and is in Aceh region, it will be directly imposed by the Qanun Jinayat. Nursiti further asserted that there is no debate among the law enforcers regarding the punishment for Khamar (drinking alcohol) and Maisir (gambling). So, in such cases, the perpetrators will be subjected to the Qanun Jinayat. However, in contrast, rape cases, especially those occurring in children, there will usually be a debate between law enforcement agencies whether to use the Qanun Jinayat or KUHP, in interview Nursiti states:

"For crimes like Khamar and maiser, the officers do not have debates with each other and they will automatically choose the Qanun Jinayat, but for cases like rape and sexual harassment, there are so many considerations especially if the victim is a child. Almost all officials agreed that for cases like child rape, they will use the Child Protection Act and will not apply Qanun Jinayat. Therefore, for the cases like child rape, all of them (the officer) agreed to use child protection act and has no debate among law enforcers but is inversely related to maisir violation and khamar will directly use Qanun because is Lex Specialis."28

Nursiti's statement above is inversely different to what happens in the field. In 2017, there was a case of child rape committed by two men in Tapaktuan, South Aceh. In this case, the Sharia Court imposed the punishment for the rape committed by M Junaidi and Tarmizi. Each were convicted of raping an underage child and were sentenced with caning. M. Junaidi was sentenced to 153 whips and Tarmizi was sentenced to 200 whips. ${ }^{29}$

27 Interview with Nursiti lecture from Faculty of Law Science: Department of law science, Syiah Kuala Univeristy, July 2, 2018

28 Interview with Nursiti lecture from Faculty of Law Science: Department of law science, Syiah Kuala Univeristy, July 2, 2018

${ }^{29}$ Hendrik, "Kejari Aceh Selatan Cambuk Pelaku Pemerkosaan Anak di Bawah Umur", online: <https://www.goaceh.co/berita/baca/2017/05/05/kejari-aceh-selatan-cambuk-pelaku-pemerkosaananak-di-bawah-umur>. 
The caning took place on April 5, 2017 at 11:30 in the morning, but the sentence was only carried out against M. Junaidi. The caning for Tarmizi was suspended for health reasons. According to the caning punishment procedure, caning is carried out gradually. After 25 canings, the health condition of the convicted person is examined by a team of doctors and if there is considered to be no health problems the punishment will be continued. Meanwhile, if the condition of the defendant's health is not good, then the caning can be suspended until the next whipping process. If the caning sentence for M. Junaidi was done to completion, then the caning for Tarmizi must be stopped due to health reasons. The caning punishment for Tarmizi was canceled three times because of his physical condition, which was considered impossible to impose a whipping punishment. According to the chief of the State Prosecutor's Office (Kajari) in South Aceh, Munif, the whip execution for Tarmizi was canceled and stopped completely because this is the third time the whip execution was conducted and failed due to unhealthy physical conditions of the defendant. Therefore, the convict should be released, otherwise this could be targeted to human rights violations. According to Munif, the penalty option is also not possible to be imposed due to the poor economic condition of the convicted. Furthermore, Munif issued a statement regarding the weakness of the application of Sharia punishment: "This is one of the weaknesses of Qanun Jinayat in Aceh, because it does not specifically regulate the implementation of the punishment of the convicted person."30

The head of the investigative section of public order enforcers (Satuan Polisi Pamong Praja/SATPOL PP) and the Sharia Police (wilyatul Hisbah/WH), Marzuki, agreed with Nursiti's statement that law enforcement officers, when faced with child rape case, will directly use child protection law. However, Marzuki also explained why, in the field, many cases of rape and sexual abuse are punishable by caning. Marzuki explained that the police apparatus brings the case to the District Court, but then the District Court refuses to examine the case and submit the case to Sharia Court. In interview, Marzuki explains that:

"In the case of rape and sexual harassment the police officer chose to use child protection law but when this case was bring to district court level, they rejected the case and transfer this case to Sharia Court therefore this is still a problem at law enforcement level because there is no similar perception between police, prosecutors and judges. For example, in Aceh Besar, rape cases brought to the district court were subsequently rejected and delegated to Sharia Court because the case was included in Qanun Jinayat. Acording to the Law of Aceh Government when the Qanun Jinayat has been enacted, therefore the Criminal Code does not apply. The law enforcement officers (police) see that for the

30 Ibid. 
case of rape if we use Qanun Jinayat sometimes the punishment is too light and there is no deterrent effect for the perpetrator, after the whiping punishment has been conduct, that means the perpetrator was sent free. While the rape victims still feel the trauma, and this is a problem. So, for policemen the case of child rape leaving the traumatic side for the child, so it is better to apply child protection law rather than Qanun Jinayat. Actually, in Qanun Jinayat has three methods of punishment: Whip, fines and imprisonment, in fact the judge may impose a prison sentence to the defendant if you want to speak about justice for the victim but most judges in Shariah Court specially for rape cases sentenced the canning punishment." 31

There is no mechanism regarding which law will be used when encountered with cases that can be solved with the Criminal Code, the Qanun Jinayat, and customary law. Therefore, this results in two conditions. First, great freedom and more power is given to law enforcement officers, and consequently the punishment for criminals tends to have multiple interpretations. For instance, for rape cases, law enforcement officers can decide whether to use the law of the Criminal Code or the Qanun Jinayat. The second condition is about justice for the victims. As an example, in the case of Tarmizi, his caning sentence was postponed and stopped due to his physical condition. The criminal case that is committed by the perpetrator is not a crime against himself like khamar (drinking alcohol) or maisir (gambling), but a case like rape is a crime that hurts another person, especially if the victim is a child. Victims (especially children) who have been raped not only experience physical violence but also mental violence. What happened in South Aceh shows that the Qanun Jinayat only sees the law from one side: punishment for the perpetrator but not protection of the victim. After the caning punishment was held, the perpetrator now could go back to his place where he lived in same village with the victim. Whereas, the psychological condition is worse because the victim who is still afraid and traumatised due to rape case now must face a situation in which she will live in the same location as the perpetrator. This situation certainly has an impact on the recovery process of the victim and must also be considered.

\section{PROFESSIONALISM OF LAW ENFORCEMENT OFFICIALS}

This paper also aims to analyse the professionalism of law enforcement officers, qualification standards, and the reporting systems that are included in the rationale for the choice of law that is used for the settlement of cases.

31 Interview with The head of the investigative section of public order enforcers (Satuan Polisi Pamong Praja/SATPOL PP) and Sharia Police (wilyatul Hisbah/WH), July 2, 2018. 
The professionalism of law enforcement officers and the overlapping laws of the Qanun Jinayat, the Criminal Code, and customary law creates a greater power for law enforcement officials to determine which laws will be used for the same case. The case of child rape conducted by Tarmizi in South Aceh shows that legal injustice was received by the victim; the perpetrator, who experienced the postponement of sentence, returned to his residence in the same village as the victim. This incident shows the lack understanding and knowledge of law enforcement officers who are still biased, especially in justice for the victim. Human rights violations occur not because of the imprisonment imposed for the convicted of elderly men, but when the victim does not get legal justice because the perpetrator can be free due to physical condition. In addition, the victim does not get special treatment during the recovery period.

However, there are efforts made to build the professionalism of law enforcement officials by providing legal justice through forums discussion between different law enforcers. Nursiti explains that, "Among the law enforcement officers there are actually coordination forums and those things (punishment provisions that will be imposed) to be an agreement in the coordination forums among law enforcement officers". ${ }^{32}$ Further, Nursiti explains that, for a child rape case, the policeman agree to use the Child Protection Act. In interview Nursiti said that:

"The policeman have one vote for child rape case that they will used child protection laws because the child protection aspect is stronger, compared with Qanun Jinayat because as we have found in the field if the punishment is using Qanun Jinayat the judge tend to impose canning punishment for perpetrators of child rape. ${ }^{33}$

In contrast to Aceh, where the professionalism of law enforcement officers is considered not competent enough, Malaysia also implements Islamic Law in Kelantan, Trengganu, and Kedah areas. In Malaysia, there have been efforts to try to improve the systematic administration in Sharia Law. This is to ensure the implementation of Sharia Law is more just and balanced for the community. These improvements are attempted by enhancing the professionalism of the Sharia Judiciary and legal services. Judges and employees in Sharia Courts are required to take a diploma-level course in the Islamic Judiciary at the International Islamic University in Kuala Lumpur. Furthermore, the Public Services Department recommends that judges in Sharia Courts should have law degrees before the judge receives a placement. International Islamic University is one of the top universities offering a degree level Sharia course for people who want to join the Sharia Judiciary or le-

32 Interview with Nursiti lecture from Faculty of Law Science: Department of law science, Syiah Kuala Univeristy, July 2, 2018.

33 Interview with Nursiti lecture from Faculty of Law Science: Department of law science, Syiah Kuala Univeristy, July 2, 2018. 

donesia

gal service. Prospective students who wish to enroll in this program are not only required to take civil law majors but also all subjects required for a professional qualification. In addition, the student must take a minor in a Sharia subject. After obtaining a Bachelor of Law, those who wish to join the Sharia Courts must take Arabic language training course for one year and an additional year to obtain a professional diploma course. Since 1987, many of the students that graduated from the International Islamic University with majors in Sharia Law have been accepted in Sharia Courts. In 1991, out of a total of 70 judges in Sharia Courts, 52 judges had Islamic Law Administration degrees from the International Islamic University. $^{34}$

Beside improving the quality of judges, Sharia Courts are also working to improve the quality of Sharia legal services and introduce a legal report system in the hope that this system can encourage Sharia Court Judges to provide justification of decisions taken and it will reduce time in deciding similar cases. The reforms were undertaken in an effort to improve the bargaining power and lobbying power of Sharia minded reformers in the legal field in Malaysia. Learning from Malaysia in reforming the implementation of Sharia Law, this research then examined the quality of judges in Sharia Courts in Aceh. ${ }^{35}$ Nursiti said that the judges in Sharia Courts are Sharia Law graduates, but, for senior judges, most of them did not study criminal law (Jinayat). This is because before Sharia Law was implemented in Aceh, the judges in Sharia Courts only decided cases involving civil law not criminal law in Islam. In interview, Nursiti states:

"Indeed, the judges in the Sharia Court should be a Sharia Law graduates only if the judge is senior and the old recruitment, they do not learn about Jinayat (criminal). Because before Aceh implemented Qanun Jinayat, the religious courts authority is only about family law, inheritance, divorce law that only in the civil sphere and does not touch upon criminal law whereas now Sharia Law has entered the criminal law and that specific thing is only in Aceh. When I interviewed the judges, I found that there were briefing from the Supreme Court for the judges to be placed in Aceh. The judges who were placed in Aceh were also given training by the Islamic Sharia Department. The training is conducted once a year and not all judges are trained due to the limited number of participants. Judge's knowledge is also very limited and depends on what the judge has settle. For example, when I interview the judge in Sabang, cases that have been reported like Khalwat and Maisir so that the judge only explore the matter of Khalwat and Maisir cases. If we talk and ask about the case of adultery and rape and how to

\footnotetext{
34 Maria Luisa Seda-Poulin, Islamization and Legal Reform in Malaysia : the Hudud Controversy of $1992(1993)$ at 227.

35 Ibid at 228.
} 
solve the case, the Judge replied I have never handled the case. Therefore, the Judge has never read and studied the case because they have never handled." 36

The head of the investigative section of the public order enforcers (Satuan Polisi Pamong Praja/SATPOL PP) and the Sharia Police (Wilyatul Hisbah/WH) investigation section, Marzuki explained the several conditions of Sharia Judges in Aceh that the judges assigned in Aceh were mostly civil judges. This is because when a judge is deciding criminal law cases, they often use the civil law lens and perspective. In interview, Marzuki explain that:

"Actually, the judges of court of Sharia Law who are assigned in Aceh must have the qualification of a criminal law sometimes the judge assigned in Aceh is a judge with Civil Law qualifications. Thus, when the hearing of criminal suspects is more often carried civil cases instinct. For example, in making a judge's decision more emphasis on peace is considered better than punishment. The Qanun Jinayat that the judge understands is heavier on the principle of tadabur (learning) rather than punishment." 37

To ensure fair trial in the implementation of Sharia Law, there is a need to increase the qualifications of judges and law enforcement officers in Sharia Courts. In addition, there should not only be an increase in the qualifications of judges and legal service but also efforts to establish a proper procedural and law report system in accordance with principles of justice for all levels of society. Thus, cases such as those occurring in South Aceh can be minimised to ensure victims obtain justice.

\section{NORMAL OFFENCE AND CRIME BY ACCUSATION/ OFFENSE BY ACCUSATION}

There are two types of offenses or criminal offence, in order to process the case. An offense is an act that can be imposed by law because it is a violation of the law. In the Criminal Code there are two types of offenses. The first is a normal offense in which cases can be processed without the consent of the victim. In addition, legal proceedings will continue even if the victim has revoked the report. Secondly, there is the offense by accusation, which refers to the proceedings that will processed if there are reports and consent of the victim. In the Criminal Code, cases of rape are defined as a normal offense. Article 285 of the Criminal

36 Interview with Nursiti lecture from Faculty of Law Science: Department of law science, Syiah Kuala Univeristy, July 2, 2018.

37 Interview with The head of the investigative section of public order enforcers (Satuan Polisi Pamong Praja/SATPOL PP) and Sharia Police (wilyatul Hisbah/WH), July 3, 2018. 

donesia

Code on the criminal act of rape states: "Anyone with violence or the threat of violence forcing women who are not his wife to have sex with him are punished for raping, with imprisonment for twelve years." From the formulation of the article it is seen that rape is classified as a normal offense and is not included as an offense by accusation. Whereas in the Qanun Jinayah in Article 52, Paragraph 1, there is the obligation to include early evidence by the victims of rape. Article 52, Paragraph 1 shows the tendency of rape case to include to the offense by accusation. Nursisti states that in the Qanun Jinayat there were no offenses by accusation, that all offenses were classified and treated as a normal offense. In interview, Nursiti explains that:

"In Qanun Jinayat there is no separation between normal offense and offense of accusation, as it is written in Qanun Jinayat that all chapters enter into the normal offense. Referring to Article 52, paragraphs 1 and 2 , the article does tend to be ambiguous, whereas in the first chapter it refers to the fact that at the time the rape victim reports she or he must bring in the initial evidence. But then the second chapter explains that if the authorities find a case of rape, the investigator is obliged to conduct an investigation to find early evidence of rape case." 38

Article 52, Paragraphs 1 and 2 of the Qanun Jinayat, show that there are two different conditions. Article 1 states, "anyone who confesses to being raped can file a report to the investigator about the person who raped her by including early evidence." This explains that the victim who reported the rape case must automatically include the evidence of the crime. Article 2 states, "Every crime of rape is known, the investigator is obliged to conduct an investigation to find the initial evidence." This statement explains if the investigator is aware of a rape case, the investigator is obliged to find early evidence.

According to Nursiti, the two articles are not mutually contradictory but complementary. The problems originally discussed were created by this more open space for law enforcement officers when they receive reports on cases of sexual violence that have occurred, and law enforcement officials tend to wait to report from the victim rather than taking the initiative to act immediately or submit the case for customary settlement. In interview, Nursiti states:

"Actually, the article is complementary, but the investigators often think that this rape complaint submission is not a normal offense, so they will not respond. if law enforcement officers have heard there has been a rape case they wait until the victim came to report because in their

38 Interview with Nursiti lecture from Faculty of Law Science: Department of law science, Syiah Kuala Univeristy, July 2, 2018 
mind (law enforcement officers) rape case is offense by accusation. As a result, in North Aceh many cases of rape are resolved customarily." 39

The statement of the informant gives an example of how Article 52 Paragraph 1 has been interpreted by law enforcement officers as the obligation to provide legal protection for the community by acting quickly, and, when receiving reports of cases of sexual violence and rape, law enforcement agencies wait for reports from victims. This has resulted in many cases of rape, especially those occurring in the Aceh region, to be resolved customarily. Sanctions that have been imposed for the perpetrator include marriage to the victim, fines, or compensation. There is even a form of punishment in which the perpetrators and victims are expelled from the village where they live.

\section{RAPE CASES THAT ARE RESOLVED WITH CUSTOMARY LAW}

The resolution of rape cases that uses customary law often occurs in North Aceh. This is reinforced by the release of the Regent Regulation on the implementation of Dayah Education in Article 10 Point 3 which states that, "if tengku/ustad/guree commits a violation in the form of immoral act it will be processed according to the law which implies that a violation of immoral acts committed by the caregiver can be criminalized by the authorities, if it cannot be resolved customarily." The existence of the regulation clearly shows that there are legal products that encourage cases of sexual violence to be conducted by the Teungku dayah (head of an Islamic boarding school). These are completed first through negotiations or a peace agreement and then brought to the legal path if there is no peace between the victim and the perpetrator. Traditional settlement is done in two forms: making a letter of agreement that usually involves peaceful money agreed by the victim and the perpetrator or the marriage between offenders and victims. ${ }^{40}$ Another case showing violence against rape victims, who later became exposed to customary law, occurred when a girl was raped in Labuhan Haji, South Aceh. The perpetrator was sentenced to whipping punishment. But, strangely, the victim actually received the customary punishment from the community because it was considered as a village disgrace. The victim and the family were eventually expelled from the village. In interview, Nursiti states:

"In South Aceh, the girl was raped and brought to court where the perpetrator was sentenced to be flogged. But in the village the victim

39 Interview with Nursiti lecture from Faculty of Law Science: Department of law science, Syiah Kuala Univeristy, July 2, 2018

40 Faradilla Fadlia \& Ismar Ramadani, "Dayah and Sexual Harassment Againts Women in North Aceh (An Analysis for Space and Power Relation in Dayah" (2018) LIPI. 
(women) are still exposed to customary law, the victim remains accused of immoral act and expelled from the village with her family (the victim's mother) (2016). In this case the victim in his village is not considered as a victim but as the perpetrator and the reason community drive out the victim from her house because it is considered the victim can bring disaster to the village such as crop failure and disgrace for the village." 41

The explanation above can provide an overview of how the law provides layered violence for women. Such as the case in Labuhan Haji, the victim received punishment from customary law even though the victim received justice through Sharia Law (the Qanun Jinayat). The customary settlement of many cases in North Aceh show the low priority of the settlement of cases of sexual harassment and rape which are considered customary crimes that can be resolved customarily. In simple terms, some forms of violence and crimes against women, such as violence, sexual harassment, and rape are not considered criminal acts that must be resolved through applicable law.

\section{EVIDENCE OF RAPE CASES IN THE QANUN JINAYAT}

The system of proof in Islamic Law is based on the Qu'ran, As-Sunnah, and Ar Ra'yu, or the opinions of Islamic scholars (Ulama) and jurists. Evidence in the case of adultery requires that four male witnesses see the event with their own eyes. Nevertheless, the Ulama agree that a case of adultery can be proved by confession or testimony. But, the scholars differ on the view of the condition of confession that is considered valid, such as how many times the confession should be made and what happens if the perpetrators revoke the confession. The condition of pregnant women affected by the case of adultery is also a debate. The debate centers on whether pregnancy can be proof that a woman has committed an act of adultery. The Ulama agree that when a person who has been sentenced on a confession basis and the defendant ran away from the sentence, then the case should not be pursued, and the defendant is considered to withdraw the confession. The Ulama agree that the four witnesses should testify unanimously and explicitly that they actually saw the penetration act. Furthermore, the Ulama also agree that a witness should give a personal, verbal testimony and should reinforce the respective testimonies of time, place, and details of events. ${ }^{42}$

Alyasa Abubakar, former Head of the Islamic Sharia Department, explains that there are three ways of proving the act of adultery in the Qanun Jinayat: tes-

\footnotetext{
41 Interview with Nursiti lecture from Faculty of Law Science: Department of law science, Syiah Kuala Univeristy, July 2, 2018.

42 Sidahmed, supra note 16 at 198-199.
} 
timony, confession, or a DNA test. Evidence through testimony can be proved if it has several conditions:

"A testimony that would be regarded as lawful if given by a person, all of which bear testimony of the same act, committed by the same person, occurring at the same time and place. If these four witnesses testify differently, for example, the first witness saw the two of them commit adultery the next morning while another witness saw it in the afternoon, then the testimony was considered invalid. Likewise, if a witness confesses to having seen them commit adultery, while other witnesses only see them sleeping together in the same room, then the testimony is considered not enough as evidence. If the accusing person or law enforcement officer does not have four witnesses who meet the above requirements, then they shall not accuse or prosecute the person for the crime of adultery. If they do so, these accusers are considered to have committed a criminal act of Qadzaf, which accuses people of committing adultery without legal proof. They can be brought to justice and will be punished 80 times." 43

This research examines how the implementation of the Qanun Jinayat can reverse the position of the victim to be the perpetrator. Getting four witnesses in the case of Zina (adultery) is almost impossible under normal circumstances. A case in $\mathrm{Su}-$ dan shows how a rape case could fall into an act of adultery. A widow named Hajjah Suleiman was raped by two men at the time the victim was picking dates in the family garden. After four months, Hajjah found out that she was pregnant. Hajjah later reported the incident to the police because she was afraid her family would punish her for having baby without being married. The police then accused Hajjah of committing the act of Zina (aldutery) on the basis of Hajjah's position of having been pregnant outside a legal marriage. Law enforcement officials ruled out Hajjah's report on the incidents of rape and the judiciary decided to impose a stoning punishment. The court made the decision because it argued that it was very difficult and almost impossible that the woman did not enjoy and want the sexual intercourse. But then the Supreme Court upheld the alleged rape suffered by Hajjah and did not consider it an act of adultery. Finally, the Supreme Court overturned the criminal court ruling and released Hajjah. The case shows the injustice suffered by the victim who was found guilty of an act of adultery even though the victim reported there was an incident of rape. ${ }^{44}$ The above events show how the legal system does not provide protection and support for victims. As in the example of the case of Hajjah, she is a poor woman, a young

\footnotetext{
${ }^{43}$ Alyasa abubakar, "Pembuktian Zina dalam Qanun Jinayat - Serambi Indonesia", online: 〈http://aceh.tribunnews.com/2018/04/19/pembuktiab-zina-dalam-qanun-jinayat〉.

44 Sidahmed, supra note 16 at 198-199.
} 

donesia

widow, and has no protection from the family who eventually became a victim. It is common for a rape victim to hide what she experiences because of fear and shame.

The Qanun Jinayat arranged that pregnancy cannot be used as evidence of an act of adultery referring to Article 36: "women who become pregnant out of wedlock cannot be accused of committing adultery without sufficient evidence." Nursiti asserted that the proof in the Qanun Jinayat refers to the seven evidences. "Qanun Jinayat acknowledged seven instruments of Evidence, Witness, expert, letter (visum), statement of defendant, defendant's confession, evidence and IT (electronic evidence) $)^{45}$. Still, according to Nursiti, so far there has not been a case of rape that falls into the act of adultery in Aceh after the Qanun Jinayat was implemented. However, there are cases of unregistered marriages that fall into adultery. This happened in Aceh Besar and Central Aceh. In interview, Nursiti states:

"So far we have not received a judge's verdict from rape case to adultery case but that we find in the field the case of unregistered marriage becomes adultery. The couples who have been married but unregistered. However, people in the village is not recognised that marriage and reported for fornication case. The husband and wife were separated, and both are married again to a spouse, but the former husband and wife fight with each other therefore the husband with the support of the village community report that his ex-wife conduct fornication This incident happens in Aceh Besar."

Unregistered marriages that fall into the definition of an adulterous act also occur in Central Aceh. By law, a woman accused of committing adultery performed the appropriate marriage procedure, but the decision of adultery was still imposed on the woman.

"This case occurred in Central Aceh, a woman has been abandoned and left by her husband for one and a half years. Then the woman asks with the head of village whether she wants to remarry is allowed or not. And the head of village allowed the marriage and the woman was told to pay the money to the Sharia Court for 500,000- rupiah. After that the head of the village married the woman and her spouse in the village. Then the former husband come back to the village and accused the

45 Interview with Nursiti lecture from Faculty of Law Science: Department of law science, Syiah Kuala Univeristy, July 2, 2018.

46 Interview with Nursiti lecture from Faculty of Law Science: Department of law science, Syiah Kuala Univeristy, July 2, 2018. 
woman of adultery and the woman was sentenced to whip and the person who married woman was also punished." ${ }^{47}$

In addition to the case of unregistered married which falls into an act of adultery, there are cases where the act of adultery turned into a case of rape. This incident occurred in Banda, Aceh. Marzuki said that there was a couple who was caught in seclusion at Hermes Hotel, but then the women sued the man as a case of rape. In interview, Marzuki said that:

"There are several cases of fornication that fall into rape case. This case is happening in Hermes Hotel, Banda Aceh actually the couple has committed an act of adultery but then the victim makes a report of rape case. Because the case now becomes a case of rape therefore the woman can be free from the indictment of adultery." 48

The description above explains how the proof of adultery action is regulated in the Qanun Jinayat which only accommodates testimonies, confession, and DNA tests. As for the testimony, it is considered regulated by evidence with certain conditions. Even though pregnancy cannot be used as evidence of adultery or rape, there is also an interesting case where an unregistered marriage may fall into Zina's acts. This happened in Aceh Besar and Aceh Tengah, Aceh. There were also occurances of cases of committing adultery that fall into the classification of a rape case.

\section{OATH AND THE FALL OF PUNISHMENT}

Oath is one way to abort a punishment for the offender if there is not sufficient evidence. This can be taken by a person accused of being a perpetrator. However, the existence of this oath may interfere with the applicable legal process. The victims of the rape suffered physical and mental violence, then they experienced the fear of reporting the incident to the apparatus and the need to do a visum et repetrum. However, without sufficient evidence, the perpetrator can be freed from indictments by using an oath. Nursiti explained that the incident in the field the police officers closed the information about the oath to perpetrator. "I found the incident in the field where the Prosecutor closed the information do not let the perpetrator know about it (oath), he (the defendant) could use the oath and free himself from punishment (Central Aceh) ${ }^{49}$ The existence of the oath and the

47 Interview with Nursiti lecture from Faculty of Law Science: Department of law science, Syiah Kuala Univeristy, July 2, 2018.

48 Interview with The head of the investigative section of public order enforcers (Satuan Polisi Pamong Praja/SATPOL PP) and Sharia Police (wilyatul Hisbah/WH), July 3, 2018.

49 Interview with Nursiti lecture from Faculty of Law Science: Department of law science, Syiah Kuala Univeristy, July 2, 2018. 

donesia

case above gives an opportunity for the offender to free himself from the judicial system; the offender can be free only by taking an oath and that gives injustice for the victim. On one hand, the police action that does not inform the perpetrator that the existence of this oath is wrong, but on the other hand the action is taken by policeman to punish the offender in order protect the victim.

\section{CONCLUSION}

The Qanun Jinayat has discriminated against women (victims of rape) through the existence of Article 52 Verse 1 because it has provided a greater portion of responsibility for the victims. One side incriminates the victim with a double burden of presenting a preliminary evidence when she is going to report a rape case. The Qanun Jinayat seems to have no side in protecting the victim and it even victimises the victim. Article 52 Paragraph 1 provides the negative conditions. First, cases of rape and sexual harassment are interpreted as offenses by accusation and not normal offenses by law enforcement officers. This causes rape events to not be immediately followed up if there is no report from the victim and the victim is obliged to present preliminary evidence. These conditions resulted in many cases of rape and sexual abuse that were resolved customarily. Secondly, the absence of a legal selection mechanism for rape cases that can be resolved with the Qanun Jinayat, the Criminal Code, and customary laws lead to giving greater power to law enforcement officials who can decide which law to use. This therefore creates multiple interpretations and differences occurring in the same case that would discriminate against marginalised groups. Third, the Qanun Jinayat does not have a perspective to protect victims, especially for female victims.

\section{BIBLIOGRAPHY}

Abubakar, Alyasa. "Pembuktian Zina dalam Qanun Jinayat - Serambi Indonesia", online: <http://aceh.tribunnews.com/2018/04/19/pembuktiab-zina-dalam-qanunjinayat>.

Affan, Heyder. "Dianggap merugikan, Perda Syariat Islam di Aceh diusulkan ditinjau", (23 October 2017), online: <https://www.bbc.com/indonesia/indonesia-41714022>.

Afrianty, Dina. Women and Sharia Law in Northern Indonesia: Local Women's NGOs and the Reform of Islamic Law in Aceh (Routledge, 2015).

Bohlander, Michael \& Mohammad M Hedayati-Kakhki. "Criminal Justice under Shari'ah in the 21st Century-An Inter-Cultural View" (2009) 23:4 Arab Law Quarterly 417. 
Fadlia, Faradilla \& Ismar Ramadani. "Dayah and Sexual Harassment Againts Women in North Aceh (An Analysis for Space and Power Relation in Dayah" (2018) LIPI.

Freener, Michael R. Shari'a and Social Engineering: The Implementation of Islamic Law in Contemporary Aceh, Indonesia, Oxford Islamic Legal Studies (Oxford, New York: Oxford University Press, 2014).

Gunadha, Reza. "Diskriminatif, Qanun Jinayat Aceh Akan Diadukan ke MK News - Suara.Com", online: <https://www.suara.com/news/2017/10/16/174139/diskriminatif-qanun-jinayataceh-akan-diadukan-ke-mk>.

Hendrik. "Kejari Aceh Selatan Cambuk Pelaku Pemerkosaan Anak di Bawah Umur", online: <https://www.goaceh.co/berita/baca/2017/05/05/kejari-acehselatan-cambuk-pelaku-pemerkosaan-anak-di-bawah-umur>.

Interview with Nursiti lecture from Faculty of Law Science: Department of law science, Syiah Kuala Univeristy, July 2, 2018

Interview with The head of the investigative section of public order enforcers (Satuan Polisi Pamong Praja/SATPOL PP) and Sharia police (wilyatul Hisbah/WH), July 3, 2018

Milallos, Ma Theresa R. "Muslim veil as politics: political autonomy, women and Syariah Islam in Aceh” (2007) 1:3 Cont Islam 289.

Qureshi. "The Four Schools of Law in Islam", (7 February 2014), online: Understanding Islam <https://free-islamic-course.org/stageone/stageone-module4/four-schools-law-islam.html>.

Redaksi. "Qanun Jinayat Aceh Langgar Hukum Nasional dan Internasional”, (22 October 2017), online: SEJUK <http://sejuk.org/2017/10/22/qanun-jinayat-acehlanggar-hukum-nasional-dan-internasional/>.

Seda-Poulin, Maria Luisa. Islamization and Legal Reform in Malaysia: the Hudud Controversy of 1992 (1993).

Siah, Kholidah. "Tinjauan Yuridis Terhadap Pembuktian Jarimah Pemerkosaan Dalam Qanun Aceh Nomor 6 Tahun 2014 Tentang Hukum Jinayat", (26 September 2016), online: ETD Unsyiah <http://etd.unsyiah.ac.id/index.php?p=show_detail\&id=25513>. 
The Qanun Jinayat Discriminates Against Women (Victims of Rape) in Aceh, Indonesia

Sidahmed, Abdel Salam. "Problems in Contemporary Applications of Islamic Criminal Sanctions: The Penalty for Adultery in Relation to Women" (2001) 28:2 British Journal of Middle Eastern Studies 187.

Siregar, Hasnil Basri. "Lessons Learned from the Implementation of Islamic Shari'ah Criminal Law in Aceh, Indonesia" (2008) 24:1 Journal of Law and Religion 143.

Ulya, Zaki. "Dinamika Penerapan Hukum Jinayat Sebagai Wujud Rekonstruksi Syari'at Islam Di Aceh" (2016) 5:1 Jurnal Rechts Vinding: Media Pembinaan Hukum Nasional 135.

Faradilla Fadlia got a Bachelor's degree in International Relations from Prof. Dr. Moestopo University, Jakarta, Indonesia (2002-2006) and a Master Degree in Global Political Economy at the Kassel University, Kassel, Germany (2009-2011). She is interested in politic and space issue especially gender, environment, and religion.

Ismar Ramadani is a lecturer in International Relations Department, Faculty of Social and Political Sciences, Almuslim University, Bireuen, Aceh. She graduated from International Relations Department, Universitas Muhammadiyah Yogyakarta in 2008 prior to pursuing her Master Degree at Magister of International Relations, Gadjah Mada University in 2012. Her research and writing interests are issues of violence, space, Islamic law, and women. 